\title{
Editorial
}

Com a publicação de mais este número, Cadernos Cenpec procura dar um segundo passo na consolidação de seu novo projeto editorial, inaugurado em dezembro de 2011.

Cadenos Cenpec tem por vocação estimular e promover o diálogo entre conhecimentos produzidos em experiências de intervenção direta em problemas sociais e educacionais, e aqueles produzidos em pesquisas científico-acadêmicas. Estreitar as pontes entre esses campos, adensar o diálogo entre eles, aproximar suas questões e considerar suas especificidades, acreditamos, são formas de aprofundar a compreensão dos problemas, dos limites e das possibilidades implicados no desafio comum de afirmarmos o direito de todos à educação e à cultura no Brasil contemporâneo.

Neste número de Cadernos Cenpec, predomina um tema, o ensino de Língua Portuguesa. Tendo por pano de fundo os pressupostos teóricos e didático-pedagógicos que orientam 0 ensino de língua a partir dos anos 1980, os textos publicados discutem conceitos-chave, analisam textos de alunos à luz de suas condições escolares de produção, relatam experiências de professores, debatem as interfaces entre a avaliação educacional e o ensino, analisam as relações de estudantes de Letras com a leitura, e apresentam livros com contribuições significativas sobre o ensino de Língua Portuguesa.

Os textos do dossiê Gênero e ensino de Português: o caso da Olimpíada tomam como objeto de análise os textos de alunos da edição de 2010, que foram escritos mobilizando quatro gêneros de referência: poema, memórias literárias, crônica e artigo de opinião.

O dossiê é composto por cinco textos, além da Apresentação. O texto introdutório, de Egon Rangel e Ana Luíza Marcondes Garcia, A Olimpíada de Língua Portuguesa e os caminhos da escrita na escola pública, apresenta cada um dos artigos do dossiê e explicita os pressupostos teóricos e didáticopedagógicos, a estrutura e os objetivos do programa, e os 
materiais oferecidos aos professores. Como mostram os autores, a Olimpíada partilha dos pressupostos teóricos e didático-pedagógicos do ensino de Língua Portuguesa que foram se consolidando a partir dos anos 1980 e que se encontram em documentos oficiais, como os Parâmetros Curriculares Nacionais e o Programa Nacional do Livro Didático. Dessa forma, apesar de as análises abordarem textos e condições de produção específicos da Olimpíada, não tratam apenas dessa experiência e as questões que elas levantam podem ser estendidas para outras propostas de ensino de língua baseadas em gêneros.

Os demais artigos do dossiê analisam, cada um, uma amostra de cerca de 400 textos, representativos daqueles que passaram para as fases estadual e nacional do certame. 0 artigo de Ana Elvira Gebara analisa os poemas, discutindo um elemento central para a produção desse gênero: as marcas de autoria. 0 artigo de Beth Marcuschi explora as memórias literárias, apontando um desempenho satisfatório dos aprendizes no atendimento às condições gerais de produção, ao mesmo tempo em que localiza no manejo do ponto de vista discursivo e no uso da linguagem literária as principais dificuldades enfrentadas pelos alunos. Clóris Torquato examina as crônicas, mostrando como os textos dos alunos estão orientados pelo material didático e, também, por textos que circulam nos jornais. O trabalho de Ana Luiza Marcondes Garcia e Egon Rangel analisa os artigos de opinião, apreendendo de que forma as estratégias e os mecanismos argumentativos são postos em funcionamento nos textos, do ponto de vista discursivo, textual e linguístico-gramatical. Os autores mostram que a dificuldade em reconstruir as características do auditório para representar os destinatários do discurso, decorrente também das complexas condições de produção do texto, aparece como determinante para explicar o grande número de textos que não chegam a configurar-se como artigos de opinião típicos.

Os outros dois artigos deste número de Cadernos Cenpec, que não compõem o dossiê, não se dedicam especificamente ao ensino de língua, mas guardam relações com o tema.

O artigo de Florência Miranda discute um aspecto teórico, as relações entre os gêneros textuais (ou discursivos) e as atividades sociais às quais se vinculam. Seu objetivo central é demonstrar que não se pode estabelecer relações biunívocas e simples entre gêneros e atividades práticas, pois diversas atividades podem estar implicadas em um único gênero e, reciprocamente, um mesmo gênero pode ser mobilizado em diferentes atividades da vida social. 
O artigo de Maura Maria dos Santos examina a relação de estudantes de Letras com a leitura literária, adotando como referência um quadro teórico que se concentra na sociologia de Bourdieu e nas contribuições de trabalhos contemporâneos acerca da leitura. Os resultados apresentados apontam para duas direções: as preferências de leitura declaradas pelos pesquisados revelam relativa adesão à literatura canônica, mas não se restringem às obras de prestígio. A presença de práticas de leitura não controladas pela hierarquia cultural se mostra mais forte junto aos estudantes com maior capital cultural, cujos pais exercem ocupações típicas das classes dominantes e do sexo feminino, o que contraria o quadro teórico bourdieusiano.

Neste número, a seção Ação educacional: crítica \& sistematização publica um trabalho, de autoria de Ana Maria de Mattos Guimarães, Dorotea Frank Kersch e Deise Del Sent. Elas integram um grupo de formação continuada composto por professoras do Programa de Pós-Graduação em Linguística Aplicada da Universidade do Vale dos Sinos (Unisinos), caso das duas primeiras, e da Rede Municipal de Ensino de Novo Hamburgo, caso da última. A seis mãos, relatam essa experiência, enfatizando o trabalho da professora de educação básica em uma escola que concentra alunos em situação de vulnerabilidade social. Inicialmente, a professora tentou trabalhar o tema comum aos gêneros da Olimpíada de Língua Portuguesa, o lugar onde vivo. A experiência não foi fácil, pois os alunos tinham muita dificuldade para abordar temas de seu cotidiano, marcado pelas privações socioeconômicas e pela violência. Diante disso, no ano seguinte, o trabalho da professora iniciou-se pela criação de condições de produção para a escrita significativa, pelos alunos, do gênero narrativa de detetive. Com isso, eles puderam, ao mesmo tempo, elaborar discursos sobre o lugar onde vivem e aprender aspectos linguístico-discursivos possíveis com o gênero em questão.

O entrevistado deste número é o professor José Francisco Soares, especialista em avaliação educacional. Na Universidade Federal de Minas Gerais, Chico Soares, como é conhecido, foi um dos fundadores do Game (Grupo de Avaliação e Medidas Educacionais), um dos principais centros de pesquisa sobre avaliação em larga escala no País. Na entrevista, a partir do pressuposto básico da garantia do direito à educação, Chico Soares defende as avaliações externas, mas, ao mesmo tempo, argumenta que é preciso avaliar a as avaliações. Segundo ele, é necessário aprimorar nossas formas de medir, evitar o fetichismo e a reificação dos números e investir em pesquisas para aprimorar as medidas, as avaliações e a formação de nossos professores. Chico Soares defende que boas políticas são aquelas que são escrutinadas 
num amplo debate pelo conjunto daqueles que são afetados por elas.

Os livros resenhados neste número abordam, todos eles, temas relativos ao ensino de língua e aos usos sociais da linguagem. Destacam-se obras de Anna Rachel Machado (a quem homenageamos, por ocasião de seu falecimento, apresentando suas principais obras), Artur Gomes de Morais, Carla Coscarelli, Carlos Alberto Faraco, Guillaume Le Blanc, Roxane Rojo, bem como o conjunto de textos sobre cultura escrita e letramento reunidos em livro por Marildes Marinho e Gilcenei Teodoro Carvalho.

Por fim, como revista é obra eminentemente coletiva, que envolve participação de muita gente, manifestamos nossos sinceros agradecimentos a todos os que colaboraram nesse volume: autores que enviaram originais, pareceristas ad hoc, conselheiros, revisores, transcritores, tradutores, programadores visuais, resenhistas, autores que enviaram livros para as notas de leitura. Estamos certos de que a dedicação de todos é responsável pela qualidade da revista e pela acolhida que recebemos, e pretendemos continuar a receber, de leitores com diferentes perfis: pesquisadores, gestores, professores, profissionais de Ongs e todos aqueles interessados nas questões contemporâneas relativas à afirmação do direito à educação e à cultura.

\section{MAURICIO ÉRNICA}

